Table IV.-Measured section in Burgh Castle sand pit at TG481041AVERAGE THICKNESS

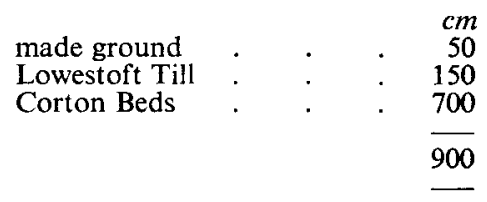

Ice wedges form in a permafrost environment: thus the presence of these casts indicates that the Corton Beds accumulated in a cold period between the two advances of the Lowestoft Glaciation. This lends support to West's tentative view that the Corton Beds are "glacio-fluvial or glacio-marine in origin, with no large amelioration of climate proven "(1961. p. 368), and his more recent description of a cold flora and fauna within the Corton Beds (in press). Table V.-Measured section in Corton Beds at TG481041 where ice
Wedge Was ReCORDED

made ground removed.
beds of alternating yellow sand and paler gravel

with shelly beds . . . . . 400

laminated clayey sand $: \quad: \quad \cdot \quad \cdot \quad: \quad 115$

pale yellow to orange sand base not seen $\quad 255$

Wood \& Harmer (1872) and Baden-Powell \& Moir (1942) correlated similar shelly sands and gravels in north-east Norfolk with the Corton Beds of Corton and south-east Norfolk. The correlation of these has been in some doubt because of the stratigraphical complications thus raised (West, 1961, pp. 370-1). However, I have recorded (in manuscript) ice wedge casts within these shelly sands and gravels at Mundesley, Norfolk. The faunal and stratigraphical equivalence proposed by the earlier workers is now supported by the new climatic evidence from Corton.

1 am indebted to Dr. R. G. West for helpful suggestions and to the Nature Conservancy for supporting my work in north-east Norfolk.

\title{
REFERENCES
}

Larwood, G. P., \& FunNell, B. M. 1961. The Geology of Norfolk. Trans. Norfolk Norwich Nat. Soc., 19, 269-375.

Wesr, R. G. 1961. The Glacial and Interglacial Deposits of Norfolk. ibid., 365-375.

- \& DONNER, J. J. 1956. The Glaciations of East Anglia and the East Midlands. Q. Jl geol. Soc. Lond., 112, 69-91.

Wood, S. V. (jun.) \& HARMER, F. W. 1872. An Outline of the Geology of the Upper Tertiaries of East Anglia (in Supplement to Crag Mollusca, Part 1, Univalves). Mon. Palaeont. Soc., 25, ii-xxxi.

60 BRACONDALE,

C. E. Ranson.

NORWICH.

8th November, 1967.

\section{PRE-CAMBRIAN OF SOUTH-EAST EIRE}

StR, - Crimes and Dhonau's clarification of the stratigraphy of the rocks of southeast Eire (Geol. Mag., 104, pp. 213-221 and 400, 1967) is most welcome, and most of their correlations substantiate those made by myself at two recent conferences which have yet to be published (in discussion, Shackleton, in press ; Wright, in press). 
In particular, the correspondence of the Cullenstown Group with the sediments of the Mona Complex and probably also with the Dutch Gin Schists (Claxton, 1963), which outcrop in Pembrokeshire on the opposite side of St. George's Channel, would now seem to be reasonably secure.

I have suggested, however, that the migmatites of the Rosslare Complex are comparable with those of the Mona Complex of Anglesey and Lleyn, but Crimes and Dhonau's description of the Rosslare rocks does not now bear this out. However, the rocks would appear to have a close correspondence with the Johnstone "Diorites" of south Pembrokeshire which have many points of similarity with the Malvernian "gneisses" (Table I). Neither of these groups is in any way similar to the Lewisian, and I think it inadvisable to attempt a correlation of a gneiss complex with the Lewisian on the basis of two periods of metamorphism separated by a period of basic dyke intrusion. This simple picture is not a realistic assessment of the Lewisian as a whole and basic dykes, which have frequently been subjected to metamorphism and deformation, are of frequent occurrence in the late Pre-Cambrian rocks of South Wales and the English Midlands.

The Malvernian, from recent isotopic age determinations (Lambert \& Rex, 1966 ; Lambert in discussion of Shackleton, in press) ; would seem to be a plutonic phase of a much later orogenic cycle, between 700 and $590 \mathrm{~m} . \mathrm{y}$, although the relations between these plutonic rocks and any of the sedimentary and volcanic rocks of this cycle are still unresolved.

\section{Table 1.-Successions of events in Plutonic Complexes}

\section{Malvern Hills.}

Malvernian.

Metamorphic event affecting Diorites and Dolerites, 590 m.y.

Basic Dykes.

Pegmatites and Hybridization

Malvern diorites, and Gabbros.

Formation of Malvernian Gneisses (Deformation and high grade metamorphism of ? sediments).
South Pembrokeshire. Johnstone Diorites, and Dutch Gin Schists.

Amphibolization of Dolerites (Retrogression of Dutch Gin Schists).

Basic Dykes.

Hybridization of Diorites. Johnstone Diorites.

Formation of quartzofeldspathic and basic gneisses. (Equivalent to garnet grade metamorphism of Dutch Gin schists ?).
Rosslare.

Rosslare Complex.

Metamorphism and deformation.

Basic Dykes.

Granitic sheets.

Formation of Rosslare amphibolites and schists.

\section{REFERENCES}

Claxton, C. W. 1963. An occurrence of regionally metamorphosed Pre-Cambrian schists in South-West Pembrokeshire. Geol. Mag., 100, 219-223.

LAmbert, R. St. J. \& Rex, D. C. 1966. Isotopic ages of minerals from the Pre-Cambrian complex of the Malverns. Nature, Lond., 209, 605-606.

Shackleton, R. M. In press. The Pre-Cambrian rocks of Wales. In A. Wood (Ed.) : The Pre-Cambrian and Lower Palaeozoic rocks of Wales. (Aberystwyth Conference, January, 1967).

WrIGHT, A. E. In press. The Pre-Cambrian rocks of England, Wales and South-East Ireland, in Proceedings of the Gander Conference, September, 1967, Mem. Am. Ass. Petrol. Geol.

Department of Geology,

A. E. Wright.

UNIVERSITY OF BIRMINGHAM.

1st November, 1967. 
SIR,-We are pleased to note that Dr. Wright accepts our correlation of the Cullenstown Group with part of the Mona Complex, but we must point out that we have at no time correlated either of these units with the Dutch Gin Schists as might be inferred from his account.

Dr. Wright's comments on our tentative correlation of the Rosslare Complex with the Lewisian have been read with interest. His alternative double correlation of the Cullenstown Group with the Dutch Gin Schists, and the Rosslare Complex with the Johnstone Plutonic Series is not only lithologically, structurally, and metamorphically improbable (Claxton, 1963; Crimes \& Dhonau, 1967), but is also logically inconsistent because the Rosslare Complex is older than the Cullenstown Group, whilst the Johnstone Plutonic Series intrudes the Dutch Gin Schists and must therefore be younger than them. It is possible, however, that both the Johnstone Plutonic Series and the Dutch Gin Schists may be broadly correlatable with the Rosslare Complex, since the latter contains a variety of sediments metamorphosed before the emplacement of basic igneous bodies which were themselves foliated before the intrusion of basic dykes.

Dr. Wright's most cogent argument for rejecting our tentative correlation of the Rosslare Complex with the Lewisian falls into two parts.

(1) There are Pre-Cambrian rocks in South Wales and the English Midlands with metamorphosed basic dykes and a metamorphic and structural sequence similar to that which we outlined for the Rosslare Complex.

(2) That these rocks are of late Pre-Cambrian age and that the Malvernian appears to be the plutonic phase of an orogenic cycle between 700 and 590 m.y.

We agree that some of the Pre-Cambrian rocks mentioned above may possibly be correlatable with the Rosslare Complex, although the latter has undergone a much more complex sequence of events than outlined in our paper and used in Dr. Wright's table. This resemblance does not by itself invalidate our correlation, especially since there is at present no conclusive evidence for accepting a late Pre-Cambrian age for any of the rocks of the Midlands or South Wales mentioned by Dr. Wright. There is, of course, ample evidence for a late Pre-Cambrian isotopic event (c. 580-620 m.y.) but such an event does not necessarily represent either the main metamorphism of these rocks or the age of their formation. With regard to the Malvernian, for example, Lambert \& Rex (1966) point out that most of the rocks which they sampled were very much altered, and the dates obtained only reflect a major isotopic event at $590 \pm 20$ m.y. They cannot be taken to prove that the Malvernian represents a 590-700 m.y. plutonic phase as suggested by Dr. Wright.

Comparison with the Channel Islands and north-west France is instructive in this context. There, basement Pentevrien gneisses are also affected by the same major isotopic event and yield mineral dates of 570-590 m.y., but as Adams (1966) has pointed out it is most unlikely that this event dated the metamorphic age of the gneisses. The gneisses have been shown on $\mathrm{Rb}-\mathrm{Sr}$ whole rock isochron studies to be much older (Adams, 1966), and Leutwein \& Sonet (1965) have also reported some K-Ar mineral and whole rock dates in excess of $1,200 \mathrm{~m}$.y.

We suggest (also Rast \& Crimes in ms.) that the Rosslare Complex, the Pentevrien, the Lewisian and possibly certain Pre-Cambrian units of the Midlands (e.g. the Malvernian and the Rushton Schists) may be part of an ancient Pre-Cambrian complex or complexes which formed part of the basement of the late Pre-Cambrian and Lower Palaeozoic "Caledonian" geosyncline. This basement and most of the later PreCambrian rocks of north-west France, the Channel Islands, the Midlands, Wales and S.E. Ireland were affected by the Cadoman orogenic episode (c. 570-610 m.y.), which we suggest may have resulted in the deformation of the Cullenstown Group and Mona Complex and possibly part of the retrogression affecting the Rosslare Complex.

\section{REFERENCES}

Adams, C. J. D. 1966. K-Ar ages from the Basement Complex of the Channel Islands (U.K.) and the adjacent French mainland. Earth and Planet. Sci. Letters, 2, 52-6.

Claxton, C. W. 1963. An occurrence of regionally metamorphosed Pre-Cambrian schists in South-West Pembrokeshire. Geol. Mag., 100, 219-223. 
Crimes, T. P. \& Dhonau, N. B. 1967. The Pre-Cambrian and Lower Palaeozoic rocks of south-east Co. Wexford, Eire. Geol. Mag., 104, 213-221.

LAMBERT, R. St. J. \& REX, D. C. 1966. Isotopic ages of minerals from the Pre-Cambrian complex of the Malverns. Nature, Lond., 203, 275-8.

Leutwein, F. \& SONET, J. 1965. Contribution à la connaissance de l'évolution géochronologique de la partie Nord-Est du Massif Armoricaine français. Colloque international de géochronologie absolue (C.N.R.S., Nancy). Sciences Terre, 10, 345-366.

Department of Geology,

T. P. CRIMES.

THE UNIVERSTTY,

LIVERPOOL 3.

SEDGWick Museum, CAMBridGe.

lst December, 1967.

N. B. Dhonau.

HIERARCHY IN STRATIGRAPHICAL NOMENCLATURE

Sir,--It is alarming to find that Mr. Hughes and his colleagues (Geol. Mag., 104, 634-5), in their revolt against the hierarchical system in stratigraphical nomenclature, are advocating the adoption of yet another " new nomenclature" with primary and secondary divisions.

Surely if a nomenclature is required for " time-scale points" we need no new system of "primary names", but some indication of where, on the existing geological timescale, such points fit. Nor would it be helpful to set up a new system of "secondary (combination) names" for "scale divisions between the time-scale points", for, if such divisions refer " to the span between any pair of points on the time scale", then these are chunks of geological time. If the "primary" nomenclature of geological time is to be free of any system of hierarchical classification, it must be divided into successive units, and only a numerical scheme seems reasonable, whether the units are years, or millions of years. If, on the other hand, one wants to refer to chunks of time with " secondary names", then each chunk must, depending on its size, include varying amounts of time, the larger being inclusive of the smaller. So we have eras, periods and ages in geology, and millennia, centuries and decades in history. These become hierarchical systems as soon as more than one grade is used.

I am surprised that our Cambridge colleagues disagree that hierarchy should be used in stratigraphy, for a hierarchical system is almost essential if it is to form the basis of a nomenclature. Nouns in any language are names given to categories in a classification. Tables and chairs are names for classes in a hierarchy which includes lower divisions (e.g. arm-chairs and dining-tables) and are themselves included in higher divisions (furniture).

So far as I know, there are only two possibilities for ordering a classification ; one is hierarchical, the other serial. Combinations of the two systems are possible and indeed usual, as in the "analytico-synthetic" or "faceted " classification of library science, which employs hierarchical categories in most of its facets. Faceted classifications may be multi-dimensional when they have a special advantage for data-storage and retrieval. They are well adapted to punched-card systems and may be handled by computers. They are ill-adapted to nomenclature, tending towards polynomials.

To my mind the best retrieval system for the classification of geological time is a scale of years before the present ; this must be serial and may or may not be hierarchical. The only nomenclatural system likely to gain international acceptance will be a compromise between rival views, and must certainly be based on hierarchical principles. The proposals for a standard stratigraphical scale put forward by the Geological Society Sub-Committee (Proc. geol. Soc. Lond., 1638, 75-87), to which I ascribe, are hierarchical. Both Messrs Hughes and Harland were members of this sub-committee. How can they now claim that a hierarchy is unnecessary?

Department of Geology, P. C. Sylvester-Bradley.

THE UNIVERSITY,

LEICESTER.

1st January, 1968. 